\section{Israeli Youth Pilgrimages to Poland: Rationale and Polemics}

In the last two decades, Israeli high school students, most of whom are third-generation Israelis, have participated in school delegations that traveled to Poland to visit Holocaust sites. These school journeys visit Jewish sites and death camps, as part of a broad-scale project that was initiated in 1988 . Over the years, the number of participants has grown steadily and by the end of 2008, 300,000 youngsters visited Poland under the aegis of this project (Vergun, 2008).

The journeys are sponsored by the Ministry of Education, and are part of the Holocaust curriculum, which includes extensive and detailed preparatory study before the youngsters leave for Poland. The Holocaust curriculum in Israel is no longer a unique school program. According to a survey by the Stephen Roth Institute for the Study of Contemporary Anti-Semitism and Racism of Tel Aviv University, the number of countries that commemorate a Holocaust Day has grown from 20 in the 1990s to 60 countries today. This trend has also been accompanied with the establishment of museums dedicated to the memory of the Holocaust, memorial ceremonies in a growing circle of countries, as well as extended media coverage and growing cultural and artistic awareness of the Holocaust. Following a conference organized by PM of Sweden in 2000, an international task force on the study, memory, and research of the Holocaust was established, with participants from 27 countries. Members in the task force assumed the mission of introducing a curriculum on the Holocaust into the educational systems of their respective countries (Hasson, 2010).

The Israeli Ministry of Education (henceforth MOE) defines the educational and social goals of the journeys and the nature of the tours, trains teachers and counselors of the delegations, and prepares the participants for the journey. Two years ago, the MOE decided to examine the extent to which these goals were achieved by the youth delegations to Poland. To this end, an interdisciplinary research team was established. In an empirical study, the team analyzed thousands of questionnaires, interviewed students, teachers, counselors, and other individuals involved in the journeys, and an attempt was made to summarize the arguments that emerged in Israel in support of and in opposition to these journeys. The following paper is based on data collected in this study.

The Jewish Diaspora has experienced mass murders in the past. The Jews were persecuted by crusader mobs in 1096 - marking the first traumatic mass-murder of Jews in Europe in the Middle Ages,
Images

vol. IX/no. 17-18

Poznań 2011

ISSN 1731-450X
1. The Diaspora -

A series of traumatic experiences with bloodshed leading to the Holocaust 
during the First Crusade. According to various estimates, 12,000 Jews in the Rheine area were killed (Graetz, 1954, Chapter 3).

The next episode of popular massacre occurred in 1648 on an entirely different scale, and is known as the Chmielnicki Massacre, where over 100,000 Jews were killed and one-third of all Jewish communities in Poland and Ukraine were completely destroyed. What began as a Cossack rebellion against the Poland, developed into a series of riots against the Jews by both Cossacks and Poles. Based on the number of victims, this Massacre is considered the largest-scale act of persecution since the Bar Kockva Rebellion[1] (132-136 AD) (Handel, 1950).

The next mass-scale trauma was related to the Russian Revolution and the collapse of the Tzarist autocracy at the end of WWI. In the riots and battles between the White and Red Russian armies in the Ukraine, approximately 60 pogroms took place within six weeks, in which tens of thousands of Jews were slaughtered. The perpetrator was Symon Petlura, the supreme commander of the Ukraine army. Another "white" Russian general, Anton Denikin, who commanded all the "white" forces in Southern Russia, was also responsible for 887 pogroms: The majority (77\%) of which were carried out by his army. The total number of Jewish victims in this period of combat between Bolshevik and anti-Bolshevik factions, is estimated to have exceeded 100,000 (Guttman, 1990).

All these incidents of bloodshed, which have a place in the study of Jewish history in the educational system, obviously are overshadowed by the bloodbath of Hitler's Final Solution. As the youth journey to the sites mentioned in this paper, they are confronted with the vision of the greatest trauma to befall the Jewish people - the trauma of the Final Solution. The systematic attempt to annihilate the Jewish people was part of the bloodbath of WWII, which claimed between 50 and 74 million victims, according to various estimates, including tens of millions of civilians (Polar, 1987). The new world order which Hitler sought to establish was based on superiors and inferiors, a nation of masters and a nation of "untermenschen." The Slav nations were considered to belong to the inferior sub-human category. Other nations that were defeated and subjugated to Nazi rule also paid a heavy price including many victims. According to various estimates, between 1.8 million and 3 million people were killed by the Nazis in Poland (Ascherson, 1987; Davies, 1982, vol. 2; Gross, 1979). In Auschwitz alone, 70,000-100,000 non-Jewish Poles were killed.

The nations defined as sub-humans were explicitly designated as the wood-hewers and water haulers in service of the German master race. Still, in no event was there any attempt to cause the total annihilation of any of these nations, which highlights the unique nature of

[1] Bar Kochva Rebellion (132-136 AD): The rebellion of the Palestinian Jews against Rome. The rebel- lion was brutally squashed and hundreds of thousands Jews lost their lives. 
the Jewish Holocaust in WWII. Jews were not considered untermenschen; they were designated as vermin to be wiped out! In absolute terms, other nations paid a higher toll; in relative terms, however, no nation came close to the toll extracted from the Jewish people. This process of destruction was initiated by two foundational acts: The first occurred on December 31, 1941, when Field Marshal Hermann Goering signed a document appointing Reinhard Heidrich, chief of the Reich Main Security Office and SS security service, as head of the Final Solution of the Jewish problem in Europe. The second was the Wannsee Conference in 1942, which Heidrich chaired. The Wannsee conferences was a meeting of senior officials of the Nazi German regime held in a Berlin suburb to discuss the practical details of the Final Solution and the division of responsibility for its execution (Gerlach, 2001).

The act of Nazi extermination was unique in the timeline of acts of persecution against Jews over history. Its planning, implementation, scope, execution, and outcomes all had a deeply profound impact on the Jewish people. The enormous tragedy and the depths of its horror transformed the identity of Jews in the Diaspora. Rabbi Lau, former Chief Rabbi of Israel, stated that "not all the victims of the Holocaust were Jews, but all Jews were victims of the Holocaust" (Davidovitch et al., 2010). The circumstances of the Holocaust radically transformed the collective consciousness of the Jewish people.

Recovery from the Holocaust was a long, complex, multi-stage process on both an individual and national level. On both levels, the recovery was initially accompanied by disregard, and what some even call, a repression of the Holocaust memory.

Memory is a "social phenomenon handed down by history" (Stier, 2002, p. 2). The Holocaust, a tragedy that unified the Jewish people, contains a memory that is important for the present, a memory that speaks not only of the past but has implications for the meaning of identity and identification of contemporary social ground (ibid). The insight, which slowly filtered down in Jewish consciousness one generation after the Holocaust, that the memory of the Holocaust might serve as a tool to unify the entire nation, marked the beginning of a new process of national consolidation, eclipsed by this traumatic memory. In this way, the traumatic memory of the Holocaust increased over the years and is currently much stronger than it was in the first years after Israel won its independence (Resnik, 2003). In fact, only in the 1980s was Holocaust memory first used as a key component in the construction of national Israeli identity. Nonetheless, the process was probably more gradual, as noted by historian Hanna Yablonka. She speaks of a gradual process that began with the Eichman trial in 1961 and led to what she calls the displacement of Zionism by Judaism and the spiritual world of Jewish communities in the Diaspora (Yablonka, 2001). She believes that what happened as

2. Holocaust memory and attitudes to the Holocaust - A Metamorphosis and the Initiation of the Journeys to Poland 
a result is the domination of the Holocaust experience in Israeli society at the expense of the previously dominant Independence experience, which had emerged following the euphoria of independence and state-building. The Holocaust experience gained control over the generation that had no direct experience with the Holocaust. The "first generation" of Holocaust survivors adopted a different ethos. As historian Anita Shapira stated, "The Jewish settlement both knew and did not know about the Holocaust. The Jewish settlement both felt and did not feel the pain of the catastrophe. The Holocaust was not internalized as a formative element in the national ethos." (1989).

In the 1980s, mainstream values and myths of Israel society underwent a significant shock (Almog, 2004; Iram \& Shechter, 2001). In the first years after independence, Israeli society was dominated by a single key ethos and several secondary ethoi such as the ethos of the "Sabra" and the myth of the "Combat soldier" unified the young nation by creating a monolithic narrative (Lazar et al., 2004). Israel, established in the wake of WWII, sought to shed all signs of the diaspora, and suppress and forget all its distinguishing marks: culture, language, customs, and memories (Resnik, 2003). The figure of the New Israeli, the Sabra, which this generation sought to create, had the following attributes: his native language was Hebrew, his manner of expression was direct and blunt, he had extensive knowledge of the land of Israel, a hatred of the Diaspora, a sense of native mastery of the land, and burning Zionist idealism (Almog, 1997). The New Israeli is a speaker of fluent Hebrew, a soldier who fights for his homeland, and works the land for a living. He also strives to build a just society (Lissak \& Horowitz, 1975). This image was not consistent with the image of the survivors who arrived with painful memories from Europe (Auron, 2003). "The ethos of negating the Diaspora also affected the attitude toward Holocaust survivors in Israel...The image of the Diaspora Jews, weak of body and spirit, contrast the strong, healthy Hebrew who was strongly rooted in the pioneer ethos" (Almog, 1997, pp. 142-143).

As a result, Israel experienced a rather lengthy period of what several scholars have called the "Holocaust repression" (Auron, 2003) or "the Long Silence" (Yablonka, 2001). The state did not forget or block out the Holocaust, but it did treat it in a "minor tone." The Holocaust was relegated to the margins of public discourse.

Moreover, some believe that Israel also experienced a "negation of national Diaspora" (Don-Yehiya, 1983, Grossman, 2005; Stauber, 2000), which intentionally avoided retention of Holocaust memory, due to the connection between the Holocaust and the Diaspora. Commemoration of one was perceived as commemoration of the other. Moreover, the best response to the Holocaust, a macro-level national catastrophe, was a conspiracy of silence (Yablonka, 1998). The young Israeli state, grounded in the worldviews of its Zionist founding fathers, sought to extinguish the Diaspora and imprint a new 
form of Jewish national life. As a result, it chose to ban the Holocaust from memory as well.

The negative attitude to Holocaust survivors gradually disappeared. The 1961 Eichman trial was a milestone in this transformation. In addition, as the years passed, memories of the Holocaust naturally disappeared from public life with the death of the many Holocaust survivors who flocked to the shores of Israel after the state was established. Gradually awareness developed that the Jewish Holocaust is a memory that will fade if no organized efforts are made to preserve it (Knoch, 2008). The chronological sand clock also played its part. While a large part of the survivors refused to talk about their own experiences, and a large part of their children, the Second Generation of survivors, refused to listen to their parents' stories, the grandchildren actively sought out a direct link to their grandparents' past (Bar On, 1994). The understanding that collective memory can be preserved only through active efforts also led to the establishment of the Poland journeys.

The decision to initiate trips of young Israelis to Poland, to visit the horrors of the Holocaust and human evil, after 40 years of silence, was an expression of new undercurrents that gradually began to flow in Israeli soil (Iram \& Shechter, 2001): The failure of the October 1973 War, the War in Lebanon, the depreciation of values, the weakness of human memory, the gradual disappearance of myths, the social crisis, and the distance in time (Keren, 1985). To this we should add that the profile of Israel's Jewish population in 1980s was completely different from that of the 1940s and 1950s. Neither was the Zeitgeist of the 1980 s similar to that of the 1940s, 1950s, or even the 1960s. The proportion of traditional and religious Jews increased significantly, the generation of socialist founding fathers who led the country until the 1970s died out. Globalization and right-wing social philosophy took a hold on Israel in the wake of the political upheaval that put an end to the dominance of the Labour party in Knesset and shook the country in 1977. All these developments rocked the foundations of the country and transformed the existing order. The memory of the Holocaust assumed new significance in the national order of priorities. Within the deep social changes that affected Israel since the 1970s, traditional Jewish and religious markers were increasingly used to mobilize Israelis around national goals (Liebman \& Don-Yehiya, 1983). The Holocaust was likened to the destruction of the Temple, and the establishment of the State of Israel - to salvation, as destruction and salvation became two important code words in the symbolic world of a large part of the population.

The beginning of this transformation can be traced to the Eichman trial in 1961, which was defined by Yablonka as a most important milestone in transforming the Holocaust into a key element in Israeli identity. According to Yablonka, the trial was a formative experience for the younger generation at the time. The trial was 
"a turning point that triggered the opening of Israeli society's deepest core to the survivors, to their stories, and to the spiritual and cultural world that they apparently had left behind them. This opening also bred a deep yearning for their world, accompanied by a deep sense of empathy." (Yablonka, 2001). While the trial, initiated by PM Ben Gurion, was designed to allure Israelis into a patriotic collective experience and national catharsis (Segev, 2010), the acceleration of this trend is typically attributed to the October War of 1973 (Graetz, 1995; Liebman \& Don-Yehiya, 1983; Zerubavel, 2002). Ultimately we can say that the role of the Holocaust increased in Israel's collective memory and in what is called Israel's "civil religion" (Feldman, 2001). Consequently, awareness developed of the need to examine and confront the Holocaust's impact on social and national identity (Wetzler, 1996).

In effect, it was a reassessment of the sources of Israeli identity that also contributed to youngsters' journeys to Poland. The trips served both what anthropologists call the link between social memory and place (Jarman, 2001), as well as what this discipline calls the "three-dimensionality of memory," where the three sites are place, time, and relationality (people's attitudes, both to place and to people) (Degnen, 2005). This experiential project was intended to reinforce the connection between the individual and the group, and between past and present (Fentress \& Wickham, 1992), even if this was not explicitly defined as such in advance.

Moreover, right from the beginning, these trips were consistent with the social science perspective, according to which places are not merely milestones but locations of social significance. Each site that has social significance has a "dwelling perspective" and holds within it the indications of all those who dwelled in it in the past and left in them the remnants of their lives (Ingold, 1993). From this perspective, a site is a symbol of its past dwellers (Hirsch, 1995). Thus, the journey to the sites in Poland creates a link between the travelers and those who occupied the Holocaust sites in the past; just as a walk in the alleys of the Old City of Jerusalem may contribute to a supposedly personal connection of contemporary Jews to their collective past (Heilman, 1986). The trip to Holocaust sites is designed to rehabilitate the link between contemporary Israel and those killed by the Nazis, who were branded by the young State as "sheep to slaughter," and to reinstate the historical continuity between Israel and the Diaspora, which attempts had been made to sever. The cleavage had manifested itself in the Zionist narrative that sought to base the history of modern Israel on identification with the ancient nation of Israel, and disassociation from and negation of the nation's Diaspora past (Rubinstein, 1977; Rahat, 1983; Shapira, 1999). Due to the normalcy to which Zionist aspired to achieve, and the revolutionary nature of Zionism, a stereotypical and at the same time dichotomous image emerged, juxtaposing the Diaspora Jew and the "New Jew" in Israel as reverse images 
(Auron, 2010). One of the results of such dichotomization was New Israel's disassociation from the Holocaust, discussed above.

Persecution and destruction of the Jews by Hitler represented extreme evil in the Diaspora. The victims of persecution were identified as "others" - These were Diaspora Jews who had no understanding of the Zionist agenda and therefore remained in Europe (Zerubavel, 2002). Moreover, identification with the Holocaust victims, who were conceptualized as "sheep led to slaughter", had a prejudicial impact on the image of the Jewish settlement in Israel at the time. This explains why identification was diverted from the Holocaust itself to Holocaust heroism and heroes such as the ghetto fighters (Shapira, 1992). Yet the process that began with the Eichman trial accelerated and within a single generation, the Holocaust became one of the foundational events in collective Israeli consciousness and a historic symbol of Jewish vulnerability (Ben-Amos \& Bet-El, 1999). Since the 1980s, the Holocaust memory has become a key component of Israeli identity. According to Witztum and Melkinson (1993, p. 236), "The Holocaust features prominently as a fundamental trauma. Everything is filtered through the memory of the cumulative furnace where one-third of the Jewish people were destroyed: Every threat, real or imaginary, is intensified and assumes new form under the influence of the Holocaust. The Holocaust has left an indelible mark on the national soul."

Interestingly, two of the most important founding fathers of modern Zionism - Theodor Herzl and Chaim Weizmann - predicted the Holocaust (each in his own way), and therefore felt the urgent need to establish a Jewish state as a preventive measure and a means of mitigating its destructive impact. Herzl predicted the catastrophe that would strike European Jewry although he admitted that he could not envision all it details (Herzl, 1929, p. 129):

I am unable to imagine the appearance and the forms that this matter will assume. Will it be an expropriation of power, a bottom-up revolution? Will it be confiscation driven by a top-down reactionary force? Will we be expelled? Will we be murdered? I imagine that all these forms together and others." (Emphasis added). Elsewhere, Herzl wrote (1937, p. 266), "I am not speculating in catastrophes, but it will also brutally strike Hungarian Jews, and the later it comes, the more severe it will be. The stronger the Jews become, the wilder the form it will take. There is no salvation from it." (emphasis added).

In 1937, following his meeting with a member of the Peel Committee[2], which developed a partition program for mandatory Palestine, Chaim Weizmann, president of the Zionist Organization, also expressed his sense of impending doom to his personal secretary,

[2] The Peel Committee: An Imperial Committee established by the British government in August 1936

in order to investigate the roots of the Palestinian
Arabs' rebellion against Britain, and draw reccommendations for the future. 
Yehezkel Saharov [later Sahar] (future Inspector General of the Israeli police,) (Rose, 1990, p. 203):

I anticipate the destruction of Jewry in Europe. This explains the enormous significance of the proposal [to establish a small Jewish state within the borders of mandatory Palestine alongside a large Palestinian state]. The size of this state is of no importance - we will be independent. We will be able to save many of them, (emphasis added).

In his speech to the Zionist Congress plenum in Switzerland, Weizmann reiterated his sense of a future holocaust that would affect all European Jewry. He did this out of a desperate attempt to convince Congress representatives to adopt the partition plan drawn up by the Peel Committee, which had been established by the British mandatory government. Weizmann believed that a Jewish state, no matter how small in size, would mitigate the devastation of such a holocaust.

I told the [Peel] Committee, God promised Palestine to the Jews. This is our charter. But we are people of our times, our horizons are limited, and we have a heavy responsibility to future generations. I told the imperial committee that six millions Jews hope to emigrate, and then I was asked, 'Could you bring six million to Palestine?' I replied, 'No. I know the laws of physics and chemistry, and I know the power of material considerations. In our generation I would divide this number in three, and thus you will understand the extent of the Jewish tragedy: Two million young people who had their lives ahead of them, who lost the most basic right, the right to work.'

"The old people will die our. Some will bear their destiny, other will not. They are like dust in the wind, economic and moral dust in a cruel, evil world. And once again I thought of our tradition. What is this tradition? It is a telescopic memory. We remember. Thousands of years ago we heard the words of Isaiah and Jeremiah, and my words are no more than a faint echo of the words of our judges, our poets, our prophets. Two million, maybe less. The remnant, the survivors. We must accept it. The rest we must leave to the future, to our youngsters. They will feel and suffer as we do, they will find a way. At the end of all days." (emphasis added)

As time passed, this awareness returned to a prominent place in national consciousness, and the understanding that had the State of Israel existed during WWII, the extent of the Holocaust could have been reduced. The existence of the State of Israel is perceived as a guarantee against a second holocaust. The trips to Poland are designed to reinforce this understanding in the hearts of the younger generation.

In this context it is notable that the topic of the Holocaust was absent from school curricula for about thirty years. Only in 1979 did the MOE first commission two curricula devoted exclusively to the Holocaust.

Furthermore, we must take into account that the large scope of the journeys to Poland must be understood in view of the metamorphosis that occurred in the attitude toward the Holocaust. To summarize this transformation, we reiterate that in the formative years of 
Israeli society - the 1940s and 1950s - collective identity was based largely on its contrast to Diaspora Jewry, and the conception of the Holocaust as an expression of its ultimate failure. This situation was reversed in the late 1970s, when the Holocaust became an anchor for Israeli identity. Historian Segev states,

Over the years, there were those who had distorted the Holocaust, exploited it, amused themselves with it, commercialized, it. As they became aware that their secular essence alone is unable to offer them an identity with roots, many Israelis became addicted to the heritage of the Holocaust as a kind of popular ritual and occasionally bizarre worship of memory, death, and kitsch. At one point, the Holocaust became one of the sources of collective identity, as it was for its six million victims." (1992, p. 9).

Some have argued that the Holocaust memory has become an anchor for the redefinition of Israeli identity based on Jewish, humanistic, and secular values (Ronen, 2003), although others contest the role of the latter two elements in the reconstruction of Israeli identity (Zuckerman, 1992: Elkana, 1988).

Trips to Poland were therefore intended to pour new meaning into the various dimensions of the Holocaust, as a derivative of one of the basic facts of sociology of the past: our social environment is what determines the manner in which we remember the past (Zerubavel, 1996). As noted above, the social driver of Israel in the 1980s was dramatically different from that of the 1940s, 1950s, or 1960s (Eisenstadt, 1989; Soen, 2003). Therefore, the memory of the 1980s is not identical to the memory of the 1940s, 1950s, or even the1960s. The very same past appears differently in both periods because a considerable portion of "memory" is filtered in the interpretation that is prevalent in the social milieu. This filtering affects both the facts that are remembered and the "tone" of the memories (Zerubavel, 1996). Nonetheless, Israel's past memory and its role as a "memory community" differ from the memory of the same past viewed by non-group members. The collective memory of the Israeli memory-community also differs from the individual memories of its own memories. For example, the contemporary collective memory of the Holocaust in Israel is more than the sum total of the Holocaust memories of all Holocaust survivors living in Israel (Zerubavel, 1994).

Due to all these, the trips to Poland are also a tool to convey and instill a specific worldview, and the educational stream that organizes the journeys became an issue with significant implications (Hazan, 1999): Would it be the public-secular stream, the religious stream, the Kibbutz stream? Attention should also be directed to the comment by anthropologist Hazan, who pointed out that the Holocaust delegations are a taken-for-granted element of Israeli educational reality, and therefore the Holocaust is perceived differently through the eyes of the delegation members. He stated,

Viewing the Holocaust through the eyes of these delegations and their journey journals offers unique access to the dynamics of social commem- 
oration and social amnesia. It emphasizes the fragility of collective memory: the memory of one person is the forgetting of another. Jewish history, for example, is perpetuated in religious schools but is absent from secular Kibbutz youth groups.

In any case, one thing may be stated with considerable certainty: After twenty years, the delegation journeys to Poland have become embedded in the Israeli educational experience and function as a kind of "rite of passage" for youngsters. Just as the backpacking experience characterizes the young adults in their twenties, who leave for an extended trip overseas after completing their army service, the journey to Poland is a feature of high school students in their teenage years. Participation in the delegations has become so conventional that students who are unable to participate for financial reasons consider such nonparticipation as exclusionary (in the last five years, delegations comprised three times the number of students from high-income groups as from low-income groups) (Lapid, 2010).

In this context, it is illuminating to hear the complaints of a group of low-income youngsters from one of Tel Aviv's poorer neighborhoods, in a recent conversation with a media representative.

It shouldn't be like that...that even the Holocaust memory has become a matter for rich people only. What are they thinking? Because we're from Jaffa, we don't care? That only kids from Savyon [ultra-rich suburb of Tel Aviv] need to sing Hatikvah at Auschwitz? That if we're poor then we don't have to study about it?..."

"This isn't a school trip....we're talking about our heritage, that is being denied us only because we don't have the money to finance [the trip].

The decision of these youngsters to publish an online petition and enroll 100,000 signatures (by February 2, 2010, 111,500 individuals had signed) to encourage the MOE to provide the proper funding is also first-rate evidence of the significance that youngsters attribute to the pilgrimage trip.

3. "I am seeking my brothers" - Development of the pedagogical Holocaust curriculum and integration of the Poland journey in the curriculum
In 1983, the Kibbutz Haartzi[3] and the United Kibbutz Movement[4] (Takam) first sent delegations of youngsters to Poland. However, only after the visits of the Director of Society and Youth Department at the MOE, and the visit by Yitzhak Navon, then Minister of Education, was a decision made to develop an experimental Holocaust curriculum, the climax of which would be in a journey to Poland (Shalem, 2008). In 1988, the MOE issued a special general circular entitled "Criteria and instructions for approving youth delegations to Poland" (MOE circular, 1988). This was the first declaration of the pedagogical aspects of these delegations:
[3] Ha'Kibbutz Ha’Artzi: A leftist kibbutzim movement established in Israel in April 1927. In 1996 it encompassed 85 kibbutzim.

[4] Takam: The Takam movement was established in 1981 in order merge two existing kibbutzim move- ments. In 1999 it incorporated the Kibbutz Ha'Arzi movement thereby encompassing all the Israeli kibbutzim. 
These visits appear to us as an experiment in experiences that touch upon the depths of the soul and convey, more powerful than words, a strong sense of the illustrious Jewish life that was extinguished... Our students will return from this journey with a sense of belonging to Jewish history and its heritage.

This circular emphasizes Jewish identity as a key goal of the journeys, and is accompanied by a journey booklet that centers on the national discourse (Hazan, 1999).

In 1991, the MOE issued a special circular that redefined and ratified the goals of the pilgrimage trip. The trip to Poland was described as an intermediate stage in a three-stage pedagogical process: 1. preparations for the trip, 2. the journey, 3. follow-up activities (Atzili, 1995). The official goals of the journey, according to the circular, were a product of obligations toward the younger generation, and included teaching the historic, moral, and educational significance (both Jewish-Israeli-Zionist and humanist-universalist) of the Holocaust to future generations.

The main goals indicated in the circular center on the encounter between Israeli youngsters and the spiritual and cultural wealth of the Jewish communities in Poland before WWII ("study of the Jewish space and in Poland its vitality before WWII"), an understanding of the scope and extent of the destruction that struck the Jews during the war ("to feel and try to understand the depth of the devastation"), and at the same time to draw secondary lessons from the heroism and courage of Jews in the resistance ("to appreciate the heroism of those who fought against the tyrants"), understand the nature of dehumanization which was part of the Nazi worldview("to feel the depths of Nazi depravity")(MOE circular, 1991). The intentions of the enterprise are summarized briefly:

Deliberate and re-examine the basic assumptions and thought patterns and attitudes to everything related to Jewish history, Jewish conduct during the Holocaust, values of Zionism, attitudes of Jews and non-Jews, and the values of morals and humanism (Shalem, 2008, p. 85).

When Shulamit Aloni, leader of Israel's left-wing Meretz party, was appointed Minister of Education, she expressed concern over reinforcing the youngsters' nationalist patterns of thought and behavior in response to the journey to Poland. Still, she did nothing to undermine the project which was in its infancy at the time. Another important Minister of Education, Amnon Rubinstein, also supported the trips, but through his liberal worldview, he added two goals: (1) Study of the main points of Nazi ideology, to "learn the national lesson of the need for a strong, sovereign Jewish state, and the universal lesson of the obligation to protect democracy and oppose any form of racism."; (2) Understanding of the complex relationship between Jews and Poles throughout their common history (Shalem, ibid). He also stated that the fact that the Jews were not the only victims of the Nazi regime should be stressed. According to Rubinstein, the picture 
is more complex than that conveyed in the program of the pupils' journeys.

Rubinstein's reservations were ultimately expressed in the 1994 amendment to the Minister of Education circular, and the additional of paragraphs that stress the significance of universal values in the journey:

Awareness of the complexity of Jewish-Polish relations over the generations...study of the key points of Nazi ideology...motivation and circumstances...the foundations of the totalitarian regime which led to a war against the Jews and other crimes against humanity. Learn the national lesson of the need to be strong and autonomous, and the universal lesson of the obligation to defend and protect democracy to uproot all forms of racism" (Minister of Education circular amended 1994).

The approaches of ministers Rubinstein and Aloni, who both integrated the need to teach humanistic, moral, universal, and anti-totalitarian lessons, were part of the ideological debate over the values, conclusions, and lessons that the State of Israel imparts to its children. In this debate, it was argued that the journeys to Poland serve the interests of the State, others argued that the journeys served the interests of national identity, and yet others claimed that the journeys served sectarian interests (Auron et al., 1994; Offir, 1995; Keren, 1992).

In this context, Prof Gorny, one of the leading scholars of Zionism, stated (1998) that the Holocaust and its lessons can be studied from three distinct perspectives: the first perspective focuses on presenting the universal significance of the Holocaust, and positions it in line with other instances of genocide, such as the Armenian genocide and the genocide in Rwanda (Auron, 2006), the murder of the gypsies (Guttman, 1990), and the genocide in Darfur in southern Sudan (Totten \& Markusen, 2006). The second perspective focuses on presenting the national significance of the Holocaust, which is viewed as a event unique to the Jewish people. This approach refuses to apply the word "Holocaust" to other cases of genocide. According to Gorney, proponents of this perspective adhere to "us against the world" mentality. Prof. Auron, a prominent Israeli scholar of the concept of genocide, believes that this approach conceives of the State as the heir of the persecuted, hated Jew, as in "Esau hated Jacob" (Auron, 2010 , p. 35). This perspective is accompanied by a sense of national siege, and its focuses on the need to build Israel's strength and power. The third perspective is a synthesis of the first two views. The different fundamental perspectives of the Holocaust is also expressed in the MOE's approach to the study of the Holocaust.

A review of MOE circulars on this topic clearly shows that within a short period of several years, a fundamental change is evident in the points emphasized by the MOE. While the main values emphasized in the late 1980s were particularist Jewish values, universalhumanist values were added in the early 1990s. It is imperative to note on this point that one of the issues of contention arising among edu- 
cators, school principals, and experts on the subject concerns the question of whether to focus on universal values or Jewish values in the study of the Holocaust and the journey to Poland (Cohen, 2009). For example, it appears that at least one alternative to the official journey to Poland - a program by Beit Ha'edut entitled Masa Mishoa Ligvura (a pilgrimage from Shoa to heroism) - universal-humanistic values are not a topic of engagement. The exclusive goals of this project are to extend pupils' knowledge of the Holocaust, reinforce their sense of Jewish identity and their Israeli identity (Refaeli, 2009). The MOE understood that the pupils return from the Polish trip affected by a powerful emotional experience, which is a potentially unique learning climate (Auron, 2003). Within a few short years it became clear that the encounter with the death camps reaffirms the role of Israel as the center of the pupils' lives, and reinforces the ties between individual Jews and their country (ibid). However, it seems that in order to generate more general lessons, and shift the Holocaust from the purview of the Jewish people to repressed nations wherever they may be, the universal significance must be specifically structured into the experiential curricula.

This point is highlighted by an Israeli public survey conducted by Yad Vashem in late 1999 on the importance of the Holocaust in Jewish society in Israel (Auron, 2010). Findings of the survey show that only $3 \%$ of the respondents believed that the Holocaust should be taught "so that we are more sensitive in our attitude to minorities and racism," and a mere $0.8 \%$ believed that the study of the Holocaust was necessary "so that it won't happen to any nation in the future." In contrast to this disheartening picture that emerged in the general public, a study conducted in 2007-2009 on a national representative sample of pupils, teachers, and principals (2,540 pupils, 519 teachers, and 307 principals) indicated a more balanced and positive state of affairs: $97 \%$ of the school principals and $81 \%$ of the teachers declared that reinforcement of universal-humanistic values is an important goal in the study of the Holocaust (Cohen, 2009), Nonetheless, 99\% of the principals and $93 \%$ of the teachers concurred that imparting a sense of shared destiny with the Jewish people was an important goal in the study of the Holocaust. The principals and teachers attribute greater importance to the particular rather than universal aspects of the lessons of the Holocaust.

In a survey conducted by the authors of this article, as part of their large-scale study on youngsters' trips to Poland in 2008-2009, 203 officials accompanying the journeys (including 131 members of school staff, 71 professional counselors, and 11 security personnel) responded to an item on the importance they attribute to the youngsters' discussions and debates during the journey on the values of Zionist, universal humanistic values, and Jewish-Arab relations. Of the educators, $79 \%$ attributed great or extremely great importance to such discussions, and $77 \%$ of the counselors responded similarly. 
Among the 1,923 pupils who responded to a similar question, 65\% responded similarly. These findings confirm that the participants are highly aware of the significance of the Holocaust's humanistic and universal aspects, at least in general terms.

Over the years, additional Minister of Education circulars have been issued in an attempt to improve the curriculum and direct the youngsters' strong emotional experience on the journey to learn more particular, Jewish lessons. The improvements were based on the findings of limited, local studies that examined the immediate or shortterm effects of the journeys (Lev, 1998; Gross, 2000; Romy \& Lev, 2003; Feldman, 2008; Lazar et al., 2004a). Prior to the current study in which the present authors are involved, no large-scale study has been conducted to identify the long-term effects of the journeys and whether they achieve their goals as a means of experiential learning.

4. The debate surrounding youngsters' pilgrimage trips to Poland
One scholar who accompanied such trips (Feldman, 2001), defined the youngsters' journeys to Poland as a "civil religious" pilgrimage, a setting structured as a ritualistic repetition of an act of survival, where the youngsters leave behind the life they take for granted in Israel to travel to Poland, the country of the Holocaust. The journeys, through the youngsters' encounter with the world of death and the demonstration of national symbols in Poland, are designed to bring the youngsters to greater appreciation of their country, Israel, as their life source and a target of emigration. This is effectively the main goal of these journeys.

Over the years, criticism has been directed at the pilgrimage trips. In the first years of these trips under the auspices of the MOE, critics argued that the preparations for the journeys and the definition of their goals were not sufficiently thorough. They claimed that the trip, while powerful, did not generate the desired results since insufficient attention is directed to the problems that the journey generates, problems that emerge from the unmediated encounter with tangible remnants of the Holocaust, on one hand, and the youngsters' lack of knowledge on the nature of reality at that time (Weiss, 1989). Furthermore, much criticism came from liberal and democratic circles in Israel, which argued that various cultural streams in society have appropriated the Holocaust for their own interests and are drawing conclusions from the Holocaust which are consistent with their own worldview (Hazan, 1999). Other critics stated that the youngsters' journeys appeared to be a distorted pilgrimage, a pilgrimage from Israel to the Diaspora, contrary to the natural direction for a pilgrimage, from the Diaspora to Israel (Segev, 1992, pp. 451-465). Yet other critics claimed that the journeys constitute a kind of distorted ritual and bizarre worship of death and kitsch. Author and playwright Shmuel Hasfari, son of Holocaust survivors himself, expressed this argument in his play "Hametz" which was produced in the 1990s. The main argument of this play is 
that the Holocaust narrative communicated in Israeli society is an account that fosters xenophobia and nationalism. Yet another criticism argues that the journey is effectively an admission of failure of Zionism, which was unable to provide an identity with roots, and more than anything else, the journeys highlight a grave identity crisis (Segev, ibid).

Recently, in an article that vigorously denounces the journeys, one high school teacher in Jerusalem discussed the journeys to Poland as a product of a deep identity crisis (Rowner, 2010):

The students' trips to the death camps do not serve any academic need other than the need to develop an "instant" identity for the youngsters. Is this the identity we wish to give to our children? Being a victim? [emphasis added].

What is the meaning of the annual mass trips of pupils to Poland? People say that the Holocaust memory is in danger of extinction, that the youngsters don't know enough, they don't understand, that this is the only way to teach them and, in particular, the only way "to understand," that it's best to see it with their own eyes.

Truthfully? The Holocaust is not in danger of extinction. It is more documented than any other event in history, in many continents. It is filmed, recounted, and spoken of more than ever. It is almost possible to say that it "thrives in memory." In fact, not so long ago, an almost obsessive engagement in the Holocaust became widespread, and now it constitutes a serious, weighty section in the history curriculum. It is simply false to claim that the youngsters don't know enough.

...Especially unfounded is the argument that the meaning of the Holocaust can be comprehended only in Poland. No understanding germinates as a result of a visit to the death camps, whose photographs are available everywhere, in documentary and feature films, and in volumes of written documentation. The journeys to Poland are made for other reasons covert reasons, and reasons that are not especially legitimate.

Israeli society is in a serious crisis. It is divided, segregated, and lacks a vision. In these terms, the youth are directionless, and in particular, they lack elements of identity and belonging [emphasis added].

...That is why a "miracle cure" was found, an instant solution, in the form of the Holocaust. Who can speak out against the Holocaust? It can be used to glue the cracked and divided parts back together.

Surprisingly, the youngsters and their parents responded with enthusiasm. And there you have a brief, effective package - a trip abroad under a heading that silences all criticism, because the topic is almost a "sacred" one. Obedient youngsters will not dare open their mouths in light of the enormity of the situation. The social dynamics hum beneath the surface, since the journeys are accompanied by intense emotions generated by the sense of "togetherness" that they create. The youngsters cry together, on each others' shoulders, and just like that - suddenly there is that sense of belonging, connection, and shared content that was so sorely lacking here in Israel...

There is no study material in the journey to Poland. Everything is taught in Israel during the preparations. The journey itself is designed to create the excitement and fill [the youngsters'] souls with a sense of collective identity...In terms of its procedures and contents, the journeys share elements with cult dynamics... [The youngsters] are subject to the authorita- 
tive external control of counselors who are highly skilled at creating the appropriate atmosphere, and they frequently use powerful emotional manipulations.

...We should stop for a moment and think: Is this the identity we wish to give to our children? Being a victim? Don't we have better cultural treasures to give them? And doesn't the very need for such an aggressive element attest to our complete failure?..."

Another severe argument voiced against the journeys claims that the heritage of the Holocaust that the pilgrimage trips are designed to entrench and represent is not a vision of national unity, but is rather derived from a political perspective of reality. Therefore the journeys potentially sharpen disputes and do not necessarily reinforce shared identity (Bar-On \& Sela, 1991, 58). Finally, protests have been heard against "the public wonder that is expressed as a ritualization of the death of the victim" (Ezrachi, 1985-6, p. 276). Another detailed study based on the documentation of one girl's journey to Poland with her class cautions that the trip leaves a shallow educational and emotional imprint and may generate frustration (Kassen \& Shachar, 2001). These are only the tip of the iceberg of criticism, and the actual range of opposition is much broader.

Rubinstein's amendments as Minister of Education, and the attitude of the previous Minister, Shulamit Aloni, reflected the controversy and lack of consensus over the effectiveness and significance of the trips to Poland. The debate over the nature and objective of the trips to Poland ranged on a continuum from nationality to universal humanism.

It was a debate in which even the most serious disputants contradicted themselves. The strongest opposition to the journeys, based on the nationalist connotations that the pilgrimage trips might breed into the participants, was espoused by Prof. Yehuda Elkana of Tel Aviv University, a Holocaust survivor himself, who preached to forget the Holocaust:

I see no greater danger to the future of the State of Israel than the fact that the Holocaust has been injected systematically and intensely into the consciousness of the entire Israeli public, even to that portion that did not experience the Holocaust, and to the generation of offspring who were born and grew up here. For the first time I understand the gravity of our actions, after we have, for many years, sent every boy and girl in Israel to repeatedly visit Yad Vashem. What did we wish our impressionable children to do with that experience? With closed minds and closed hearts, we recited to them - "Remember!" For what? What is a child supposed to do with these memories? For very many people, the images of horror might be interpreted as a call for hatred. "Remember" might be interpreted as a call for blind, continuous hatred.

Possibly it is important for the world to remember. Even of that I am not certain, but in any case, it is not our concern. Each nation, including the Germans, will decide on its own course, and whether it wishes to remember, based on its own considerations. We, however, should forget. [emphasis added]. I see no more important political and educational role today for 
the leaders of this nation than to stand on the side of life, dedicate themselves to building our future, and not constantly engage in symbols, ceremonies, and the lessons of the Holocaust. They should uproot the domination of the historical "Remember!" over our lives." (Elkana, 1988).

Other intellectuals, including Abba Kovner, also a Holocaust survivor and one of the leaders of the Vilna Ghetto uprising, viewed the cultivation of Holocaust remembrance as an important national element. He was not speaking from a necessarily nationalist or religious perspective:

As long as it is not too late we must attain the awareness that the Holocaust is not the obsession of the survivors, and the remembrance of the six million victims and the lessons of that period are not the business of only those who witnessed the horrors personally, but it is part of the lengthy collective memory of the Jewish people [emphasis added], and the Holocaust's place is in the historic consciousness of every Jewish generation wherever he may be.

This consciousness is one of the most important elements in contemporary Jewish identity because without it, it is doubtful whether it is possible to attain genuine identification with a positive, living, and creating Judaism. More than ever, the future of the Jewish people depends on the Jews' attitude toward themselves and their past, their magnificent heritage and the horrible tragedy, and the self-criticism that such historic consciousness necessarily demands... (Kovner, 1988).

A recent study involving 430 10th, 11th and 12th graders, conducted by the Masua Institute for Holocaust Studies located at kibbutz Tel Yitzhak, Israel, examined the contribution of the trips to the study of various aspects of the Holocaust. The study examined the responses of the pupils who solicited the services of Masua and therefore its findings are not representative of the general population. Nonetheless, the staggering findings show that the journey to Poland is only ranked in third place among the significant sources of the study of the Holocaust. According to the students' reports, eyewitness testimonies are the most important source of their study (38\% of the respondents), and in second place are films on the Holocaust (22\% of the respondents). The trips to Poland were ranked only in third place (20\% of the respondents) (Kashti, 2010).

Based on the study described above conducted by the present authors, whose findings are representative of all the schools that send delegations to Poland, $75 \%$ of the pupils believe that the activities related to the journey to Poland made a strong or very strong contribution to their knowledge on the Holocaust. Nonetheless, 78\% noted that history lessons made a similar contribution, $73 \%$ felt that the media made a similar contribution, and $72 \%$ stated that accounts told by survivors made a similar contribution to their knowledge of the Holocaust. Thus, these findings also indicate a long series of factors other than the trips to Poland, which make a similar contribution to the youngsters' knowledge of the Holocaust. The journeys' contribu- 
tion is therefore not a unique one. It is an important contributor to the understanding of the Holocaust, but other equally important contributing factors exist.

Students' reports are also joined by the contemplation of individuals who hold dear issues of society and state. For example, the general director of the Future Leadership Institute (whose academic director is Prof. Nitza Nachmias) posed this rhetorical question (Elner, 2010):

It is true that many return from the trip replete with experience and in most cases, also shocked. It is true that Israel exhibits to the entire world the great significance that it attributes to Holocaust remembrance, through the March of the Living, and the visits to the camps by thousands of pupils. But is this the best way to teach? To explain? Do the hundreds of thousands of people who do not go on this journey not understand the meaning of the Holocaust? Is this the focus of the country that was established on the devastation of its people; Are there no better ways?

According to this opinion, better and more effective ways do exist, compared to the trip to Poland: A trip to Yad Vashem, viewing movies that immortalize the horrors, as well as encounters with Holocaust survivors have the potential to teach and educate better than any journey to Poland. "The journey is a poor solution, which replaces the need to develop a unique, complex, and current study kit" (Elner, 2010). The hundreds of talkback responses (220 in number!) triggered by Elner's article supported this opinion overwhelmingly. The following, however, is characteristic of responses expressing the opposite opinion:

That's right, not everyone gets to go there and experience the same thing that I experienced, and understand the long-term significance and the depth of the issue, but for someone who does, that someone will go to officer's course and lead others, he will be a role model, he will lead a humane army. And that person, when he completes his IDF service, and goes to study, he will head a leading economic company that makes the economy in Israel strong even at the time of a global financial crisis. Because of that one person, the project is a blessing.

We should not live with the shadow of the Holocaust hovering above us, but with the memory of the Holocaust shaping our understanding and our strength as a nation. [emphasis added] And we can consider the Holocaust survivors as paragons and role models who, despite the worst catastrophe of all, came to build the state and did not mention of speak with their children about the horrors they experienced and the disasters that occurred in their families. They decided to raise and teach a new generation how much their country is important, a generation that is not afraid to ask questions, a generation whose achievements lay ahead.

I was there, and I recorded this response.

Opposed to this is the opinion of those who experienced the trip to Poland as a cataclysmic experience which afforded them a new understanding of the Holocaust (Shachar \& Katan, 2001, p. 1 online):

Four years ago I went on a tour of Poland with a group of my students. It was a painful journey to our collective past as members of the Jewish peo- 
ple. On the trip, I held the scepter of the educator, a role that I had filled in this group for five years. Over the years, we developed familiar roles and patterns, resulting from the long shared road that we have traveled together, my students and I. During the journey to Poland, I felt that the patterns and roles that had become entrenched over the years unraveled completely, lost their meaning. I felt that I myself was in need of a "Guide to the perplexed," someone to hold out a hand, to support me, to direct me. For me, the journey to Poland was my first encounter with the pain, the sadness, the rage, and the questions that the Holocaust evokes.

During the journey, at the age of 36 , the first cracks appeared in the enormous protecting wall, which had concealed the vision of the Holocaust horror from me throughout all my years as a child and an adult. At age 36 I first became aware of the "glass wall" that had denied from me the touch of pain, denied the tears. I remember Holocaust remembrance days, the assemblies, the ceremonies, the sirens, standing at attention, the Yizkor prayer. I acted like everyone else, by the rules. Stood at attention, looking downward, looking at the evidence of the horror with pity, but deep inside me - nothing was happening. There was a kind of emptiness, opaqueness, emotional numbness... as if the things don't touch me, as they never happened. I was like an actor whose appearance says nothing of what he feels inside, standing at the ceremony, following the director's instructions.

In this context, the visit to Poland became engraved as a journey into myself, a journey designed to widen the crack in the opaque wall and make its way to the pain and the tears. I considered myself as someone who comes on this journey from the same place as many of my students came. As a typical kid in his initial stages of development, whose defenses are at a test and who is in a crisis that serves as the lever for growth and development. The journey to Poland became engraved in my memory as a significant experience, not only because of the difficult sights and accompanying explanations, but especially because it was only there that I started to understand and feel, with all my senses, the pain of the mothers, the tears of the children, the cries of the families, and the grief of an entire nation.

Contrary to this pragmatic support it is not difficult to find, in the Israeli discourse surrounding this issue, support that represents the most extreme form of nationalism, the view that represents an "us against the world!" mentality, the view of Israel on one side and the perpetual enemy (Amalek) on the other. According to this approach, the trip to Auschwitz is designed to demonstrate that the enemy is alive and well. Auschwitz is the site that is designed to instill this awareness in the hearts of the youngsters, and it is this awareness that must be their guiding light (Rett, 2010).

Amalek takes different forms. Once he wears a modern suit and tie, and once he wears a kafiya and robes. Once he comes from the searing desert, and once he comes from the Ukraine ice steppes; once he speaks politely and once he roars. Once he mobilizes the academe for its interests, and once he reins in hooligans and the ignorant. Amalek is sophisticated. He takes many forms - but he has always had a single purpose: "They have said, Come, and let us cut them off from being a nation; that the name of Israel may be no more in remembrance." (Psalms 83:4). 


\section{References}

\section{Hebrew}

Almog, A. Bidding Srulik \farewell: Changes of values in the Israeli elite. Haifa: Haifa University and Zemora Bitan, 2004.

Almog, A. The Sabra - a profile. Tel Aviv: Am Oved, Ofakim, 1997.

Atzili, A. "A journey to hone Zionist, Jewish, and party values." Bishvil Hazikaron, 7, 7-8, 1995.

Auron, Y. The pain of knowing: Issues in Holocaust and genocide instruction. Tel Aviv: The Open University, 2003.

Auron, Y. "Who's afraid to talk about genocide?" Eds. H. Hertzog and K. Lahad (eds.). Knowing and remaining silent: Mechanisms of silencing and represion in Israeli society. Jerusalem: Van Leer Institute and Sifriyat Hapoalim, 2006.

Auron, Y. Israeli identities: Jews and Arabs in the mirror and the other. Tel Aviv: Resling, 2010.

Bar-On, D., and Sela, A. Psycho-social effects of the Holocaust on the second and third generations. Beer Sheva: Department of Behavioral Sciences, Ben Gurion University of the Negev, 1991.

Bar-On, D. Between fear and hope. Tel Aviv: Ghetto Fighters House and Kibbutz Hameuhad, 1994.

Cohen, A. Study on Holocaust instructions in high schools in Israel - Summary of the main findings. Ramat Gan: Bar Ilan University, School of Education and the Claims Committee, 2009.

Davidovitch, N., Lustig, R., Lieberman, G., Milgram, N., and Soen, D. Assessment of the youth pilmigrages to Poland: An examination of the moral, academic, and emotional contribution. Interim Report. Ariel: Ariel University Center, 2010.

Eisenstadt, S. N. Israeli society in tranformation. Jerusalem: Magnes, 1989.

Elkana, Y. "In praise of silence." Haaretz, 2.3, 13, 1988.

Elner, A. "Poland - not the place for youngsters", Ynet January 31, Opinions, 2010.

Feldman, J. "Following the Israeli Holocaust survivor: Israeli youth delegations to Poland, and national identity". Teoria vebikoret, 19, 2001. 167-190.

Fullerm J. P. C. The Second World War. Tel Aviv: Ministry of Defense, Ma'arachot, 1987.

Gerlach, K. The Wannsee Committee, the destiny of German Jews, and Hitler's principled decision to destory all the European Jews. Jerusalem: Yad Vashem, 2001.

Gorny, Y. Between Auschwitz and Jerusalem. Tel Aviv: Am Oved, 1980.

Graetz, Z. History of the Jews (Vol. D). Tel Aviv: Yizrael, 1954.

Graetz, N. Captive in its dream. Tel Aviv: Am Oved, Ofakim, 1995.

Gross, T. Influence of the pilgrimage to Poland under the auspices of the Ministry of Education on the processing of the Holocaust. Master's thesis, Ben Gurion University of the Negev, 2000.

Grossman, H. “The March of the Living." Kesher Ayin, 147, 2005. 12-14.

Guttman, Y. Encyclopedia of the Holocaust (Vol. A), Jerusalem: Yad Vashem, 1990.

Handel, M. The 1096 Massacre. Jerusalem: Kiryat Hasefer, 1950.

Hasson, N. "The International Holocaust Day: Antisemitism is increasing but so it's Holocaust remembrance." Haaretz, January 26, 2010.

Hazan, H. "Three faces of the Holocaust." Panim, 11, 1999. 66-75.

Herzl, B. Z. History. Translated by R. Binyamin and A. Barash. Tel Aviv: Mitzpeh, 1929.

Iram, Y., and Shechter, A. "Fifity years of moral education - from an emerging society to a changing society. A review of development." Eds. Y. Iram, 
S. Shkolnikov, Y. Cohen, and A. Shechter Crossroads: Values and education in Israeli society. Jerusalem: Department of Publications, Ministry of Education, 2001.

Kashti, A. "A poll of high school students: Films on the Holocaust are more significant than the journeys to Poland.” Haaretz, January 26, 2010.

Keren, J. The impact of public opinion on one hand and Holocaust research on the other, on Holocaust public highschool instruction methods and information education in Israel between 1948 and 1981. Doctorate thesis. Hebrew University of Jerusalem, 1985.

Keren, N. "Youngsters' journeys to Poland - second thoughts." Skira Hodsheet, 7, 1992. 46-47.

Kessen, L., and Shachar, A. “The trip that became a journey." Panim, 17, 2003. 95-107.

Knoch, H. “The search for authenticity: Memory, emotions, and testimony in contemporary Germany.” Tabor, 1, 2008. 10-23.

Kovner, A. From generation to generation. A pool of documents from the Holocaust period. Seminar Hakibbutzim, 1988. . Accessed: 1/1/10/.

Lapid, Y. “Cry for help.” Ynet Activism, January 29, 2010.

Lev, M. Impact of youngsters' journey to Poland on their cognitive and emotional attitudes toward the Holocaust. Master's thesis. Ramat Gan: Bar Ilan University, 1998.

Lissak, M., and Horowitz, D. "The ideological dimenions in the Jewish settlement's political system." Medina, Mimmshal, and Yahasim Beinleumi'im, 7, 1975. 28-61.

Ministry of Education and Culture. Criteria and guidelines for approving youth delegations. Minister of Education Circular, 1988.

Offir, A. "On feelings that cannot be expressed in words, and lessons that should not be doubted." Bishvil Hazikraon, 7, 1995. 11-15.

Rahat, R. (1983). Immigration and absorption. In Social patterns in Israel: Trends of cohesion and separation. Tel Aviv: The Open University, 1983.

Refaeli, W. Assessment of the Masa Masuah Litkuma program. Nir Galim: Beit Ha'edut, 2010.

Rett, A. “Amalek 1945-2010.” Ynet, January 28, 2010.

Romy, S., and Lev, M. "Knowledge, emotions, and attitudes of Israeli youngsters to the Holocaust." Megamot, 42, 2002. 219-239.

Ronen, A. "Recognizing another's pain: Teaching racism and the Holocaust to Arabs and Jews." Ed. A. Nahtomi. Multi-culturalism in a test in Israeli society. Jerusalem: Magnes, 2003.

Rose, N. Chaim Weizmann. Jerusalem: Domino, 1990.

Rowner, A. "The concealed goals of the journey to Poland." Ynet, August 25, Opinions, 2010.

Rubinstein, A. Being a free nation. Tel Aviv: Shoken, 1977.

Segev, T. The seventh million. Jerusalem: Keter, 1992.

Segev. T. "The Eichman trial: Wanted - teachers with integrity." Haaretz, February 4, 2010.

Shachar, A., and Katan, L. “The trip that did not become a journey." Panim, 16, 2001. online: . Accessed: 8/4/05.

Shalem, M. "In defense of the youth journeys to Poland." Hed Hahinuch, February, 2008. 84-87.

Soen, D. A land of rage and fury: Cleaveages and identity in Israel. Kiryat Bialik: Ah, 2003.

Stauber, R. The lesson for the generation of Holocaust and heroism in public thinking in the 1950s. Jerusalem: Yad Yitzhak ben Tzvi, 2000. 
Vergun, Y. Student delegations to Poland. Jerusalem. Knesset Research and Information Center, 2008.

Weiss, A. "Journey to Poland - illuminations and comments." Igeret Lihinuch, 85, 1989. 49-50.

Wetzler, A. (1996). "Fifty years later: Varying motifs in research and theory concerning the Holocaust survivors from a psychological perspective." Gerontologia, 72-73, 1996. 4-14.

Witztum, A., and Melkinson, R. "Grief and commemoration: The two-sided face of the national myth." Eds, R. Melkinson, S. Rubin, and A. Witztum. Loss and bereavement in Israeli society. Jerusalem: Kaneh and the Ministry of Defense, 1993. 231-256.

Yablonka, H. "Holocaust survivors in Israel - Initial summaries." Bishvil Hazikaron, 41, 1998. 24-31. 27.

Yablonka, H. "The Eichman trial and Israel, 40 years later." Bishvil Hazikaron, 41, 2001. 24-31.

Zuckerman, M. Holocaust in the sealed room. Tel Aviv: privately published, 1993.

\section{English}

Ascherson, N. The struggles for Poland. New York: Random House, 1987.

Auron, Y. Katznell, J. and Silberklang, D. (1994). "The Holocaust and the Israeli Teacher." Holocaust and Genocide Studies, 8, 1994. 225-257.

Ben-Amos, A., and Bet-El. L. "Holocaust Day and Memorial Day in Israeli schools: Ceremonies, education and history." Israel Studies, 4, 1999. 258-284.

Davies, N. God's playground: A history of Poland. Vol. 2. New York: Columbia University Press, 1982.

Degnen, C. "Relationality, place, and absence: A three-dimensional perspective on social memory." The Sociological Review, 53, 2005. 729-744.

Ezrachi, S. D. "Revisiting the past: The changing legacy of the Holocaust in Hebrew literature." Salmagundi, 68-69, 1985-86. 245-276.

Feldman, J. Between the death camps and the flag: Youth voyages to Poland and the performance of the Israeli National identity. New York: Berghahn Books, 2008.

Fentress, J. and Wickham, C. Social memory. Oxford: Blackwell, 1992.

Heilman, S. A walker in Jerusalem. New York: Summit Books, 1986.

Hirsch, E. "Introduction, landscape: Between place and space." Eds. E. Hirsch and M. O'Hanlon. The anthropology of landscape: Perspectives on place and space. Oxford: Clarendon Press, 1995.

Ingold, T. "The temporality of the landscape." World Archaeology, 25, 1993. 152-174.

Jarman, N. "Commemorating 1916, celebrating difference: Parading and painting in Belfast." Eds. A. Forty and S. Kuchler. The art of forgetting. Oxford: Berg, 2001.

Lazar, A., Chaitin, J., Gross, T., and Bar-On., D. “Jewish Israeli Teenagers, National Identity, and the Lessons of the Holocaust." Holocaust and Genocide Studies, 18, 2004. 188-201.

Lazar, A., Chaitin, J., Gross, T., and Bar-On, D. "A Journey to the Holocaust: Modes of Understanding among Israeli Adolescents who Visited Poland." Educational Review, 56, 2004. 13-31.

Liebman, C.S. and Don-Yehiya, E. Civil religion in Israel. Berkeley: University of California Press, 1983.

Resnik, J. "Sites of memory of the Holocaust: Shaping National Memory of the Education System in Israel." Nations and Nationalism, 9, 2003. 297-317. 
Shapira, A. "On the spiritual rootlessness and circumscription to the "here and now' in the Sabra world view." Eds. D. Urian and E. Karsh. Jewish aspects in Israeli culture. London: Frank Cass, 1999.

Stier, O.B. Committed to Memory: Cultural Mediations of the Holocaust. Boston: University of Massachusetts Press, 2003.

Totten, S., and Markusen, E. (2006). Genocide in Darfur: Investigating the atrocities in the Sudan. New York and London: Taylor \& Francis Group, 2006.

Zerubavel, E. “Social memories: Steps to sociology of the past." Qualitative Sociology, 19, 1996. 283-299.

Zerubavel, Y. "The death of memory and the memory of death: Massada and the Holocaust as historical metaphors." Representations, 45, 1994. 72-100.

Zerubavel, Y. "The 'mythological Sabra' and Jewish past: trauma, memory, and contested identities." Israel Studies, 7, 2002. 115-144. 